\title{
Genotype $\times$ Environment Interaction and Stability Analysis of Kharif Potato in Koraput Region of Odisha, India
}

\author{
Jyotshnarani Maharana ${ }^{1}$, C.M. Panda ${ }^{1}$ and Praveen Jakhar ${ }^{2}$ \\ ${ }^{1}$ Department of Vegetable Science, OUAT, Bhubaneswar-751003, India \\ ${ }^{2}$ ICAR-IISWC-RC, Koraput-763002, Odisha, India \\ *Corresponding author
}

\begin{tabular}{|c|c|}
\hline & A B S T R A C T \\
\hline $\begin{array}{l}\text { Ke y word s } \\
\text { Stability, Kharif } \\
\text { Potato, Solanum } \\
\text { tuberosum L., } \\
\text { Marketable yield, } \\
\text { Regression. }\end{array}$ & \multirow{3}{*}{$\begin{array}{l}\text { The present investigation was conducted during kharif seasons of } 2014 \text { and } 2015 \text { over four } \\
\text { different environments to study stability analysis in potato during Kharif season in Koraput } \\
\text { region of Odisha. The field study was laid out in randomised block design in three } \\
\text { replications. The } 16 \text { genotypes used in the study included released varieties, hybrids of } \\
\text { potato belonging to Solanum tuberosum sub sp. Tuberosum. Of the } 16 \text { varieties evaluated; } \\
\text { Kufri Lalit, Kufri Lalima, Kufri Pukhraj and Kufri Jyoti showed better adaptability for } \\
\text { yield/plant and marketable yield. As per the stability criteria of Eberhart and Russell } \\
\text { (1966) for yield/plant and marketable yield, Kufri Jyoti and Kufri Ashok and Kufri Khyati } \\
\text { were stable in all the locations. The mentioned varieties can be recommended to farmers } \\
\text { for cultivation for off-season potato in Koraput region. The information obtained from the } \\
\text { present study could be exploited in breeding programmes to develop superior genotypes } \\
\text { for off-season potato cultivation in the region. }\end{array}$} \\
\hline Article Info & \\
\hline $\begin{array}{l}\text { Accepted: } \\
12 \text { April } 2017 \\
\text { Available Online: } \\
10 \text { May } 2017\end{array}$ & \\
\hline
\end{tabular}

\section{Introduction}

Information about phenotypic stability is useful for the selection of crop varieties as well as for future breeding programs. The phenotypic performance of a genotype is not same under diverse agro-ecological conditions (Ali et al., 2003). Some genotypes may perform well in certain environments, but, fail in several others. Genotypeenvironment (GE) interactions are extremely important in the development and evaluation of plant genotypes because they reduce the genotypic-stability values under diverse environments (Hebert et al., 1995). The concept of stability has been defined in different ways and several biometrical methods including univariate and multivariate ones have been developed to assess stability (Lin et al., 1986; Becker and Leon, 1988). The most widely used one is the regression method which is based on regressing the mean value of each genotype on the environmental index or marginal means of environments (Tesemma et al., 1998; Nagraja et al., 2017).

A good method to measure stability was previously proposed by Finlay and Wilkinson (1963) and was later improved by Eberhart and Russell (1966). The stability of varieties was defined by high mean yield and regression coefficient (bi $=1.0)$ and deviations from regression as small as 
possible $\left(\mathrm{s}^{2} \mathrm{di}=0\right)$. The stability was defined as adaptation of varieties to unpredictable and transient environmental conditions and the technique has been used to select stable genotypes unaffected by environmental changes (Allard and Bradshaw, 1964).A number of stability studies have been carried out on different crop plants (Spaldon et al., 2017). However, stability studies for kharif season potato is lacking particular for Koraput region in southern Odisha. Keeping all these points in consideration a study was planned with the objective to evaluate the yield of promising potato genotypes in different environments in Koraput region and to determine their stability.

\section{Materials and Methods}

The Koraput region of Odisha comprises amalgamation of hills in Eastern Ghats with an altitude of $950 \mathrm{~m}$. Climate of the study area was sub-tropical and sub-humid type with mean annual maximum and minimum temperature of 30.6 and $17.0^{\circ} \mathrm{C}$, respectively. Mean annual rainfall of the area is $1450 \mathrm{~mm}$, of which $80 \%$ is received during June to October. The rainfall data during the experimental period of year 2014 and 2015, recorded at the meteorological observatory of respective block office is presented in table 1 . The effective rainfall during the period indicates the difference between rainwater and evapotranspiration. The 16 genotypes used in the study included released varieties, hybrids and exotic variety Atlantic released in USA belonging to Solanum tuberosum sub sp. Tuberosum (Table 2). Varieties for the study were obtained from the AICRP on potato centre -OUAT, Bhubaneswar. The genotypes were evaluated under four environments i.e. instructional farm of KVK-Semiliguda, villages: Luhaba (Semiliguda block), Muliaput (Nandapur block) and Jhaliaguda (Jeypore block) during kharif season of 2014 and 2015. The four locations were diverse in climate and altitude having scope of off- season potato cultivation. To analyze the soil properties representative soil samples were taken and analysis was done for evaluating the physico-chemical properties (Table 3 ) of the locations. The data indicates moderate levels of organic carbon and potassium and low available phosphorus. Each trial was laid out in a randomized complete block design with three replications. Each genotype in a replication was planted in a row spaced at $20 \mathrm{~cm}$ within rows and $60 \mathrm{~cm}$ between rows. Fertilization, weeding, other cultural practices and need based plant protection measures were followed as recommended for kharif season cultivation. Pooled stability analysis over all environments was done by following Eberhart and Russell (1966). The stability of genotypes in terms of 3 parameters namely, genotypic mean (gi), regression coefficient (bi) and deviation from the regression $\left(\mathrm{s}^{2} \mathrm{di}\right)$ was analysed. According to this model, an ideal or most stable genotype is the one having high mean performance, unit regression and no/minimum deviation from regression.

\section{Results and Discussion}

The analysis of variance revealed that mean sum of squares (MSS) due to genotypes (G) and environments (E) was highly significant (at 1\%) for both the characters (Table 4). The high significance levels of different traits of potato under pooled variance analysis indicate the presence of substantial variation among the genotypes over environments. However MSS of $\mathrm{G} \times \mathrm{E}$ interaction was significant for marketable yield only. This indicates that the trait differed between planting environment and genotypes. The significance of linear component of $\mathrm{G} \times \mathrm{E}$ interaction indicates the significant rate of linear response of the genotypes to environmental changes for these characters. The non-significant effect on pooled deviation for most of the characters indicates that linear component of $\mathrm{G} \times \mathrm{E}$ interaction was predominant. The MSS of 
environment (linear) was highly significant (1\% probability level) for both the characters.

Significant $\mathrm{G} \times \mathrm{E}$ interaction for different characters indicate that genotypes under different environments behaved differently for the expression of characters of interest. The high significance of MSS (linear) indicates that environmental effects are additive. For pooled variance analysis similar results are reported by Patel et al., (2008), Luthra et al., (2009) for potato. Since the GXE interactions were found significant for both characters of kharif potato hence the data of the characters were subjected to stability analysis. Significant differences were noticed in yield/plant across the four locations as environment index showed wide variations. Highest yield/plant and marketable yield was exhibited by the plants grown at Nandapur location with environmental index values 9.18 to -12.08 and 3.14 and -6.54 , respectively (Fig. 1 and 2).

Stability parameters for yield/plant is depicted through mean, regression and standard deviation in table 5 and presented in figure 3. Out of 16 tested genotypes only 7 genotypes exhibited greater mean value than population mean (167.6 g/plant). Out of these 7 genotypes Kufri Pukhraj had significant deviation from regression. The prominent high yielding varieties were Kufri Chipsona 3 (178g), Kufri Ashok (173g), and Kufri Lalit (175g). Minimum yield/plant was recorded in
Kufri Arun (145g). As per the stability criteria of regression approaching 1, only Kufri Jyoti reached to a value of 0.76 . This was closely followed by Kufri Ashok with regression value of 1.16. Kufri Jyoti and Kufri Ashok showed stability in all the environments. Three genotypes, Kufri Kanchan, Kufri Chipsona 1 and Kufri Chandramukhi showed regression coefficient spinning to 1 , but the mean values were less than population mean. Hence the genotypes were classified as poorly adapted to all environments. Processing variety Kufri Chipsona 1 with unity regression coefficient along with low mean values displayed average adaptability to all the environmental conditions. The set of genotypes of Kufri Lalima, Kufri Pukhraj, Kufri Lalit, and Kufri Chipsona 3 were found better adapted to unfavourable locations. Similar results for yield/plant were reported by Haydar et al., (2009).

Marketable yield showed wide variation in output under different environment locations and recorded the mean value was $93.3 \mathrm{q} / \mathrm{ha}$ (Table 5 and Fig. 4). Eight genotypes showed higher marketable yield over population mean while 8 were below the population mean. A total of six varieties had high mean values for marketable yield with significant regression coefficient value and non-significant deviation from regression. Kufri Pukhraj and Kufri Jyoti had maximum mean value of $107.4 \mathrm{q} / \mathrm{ha}$ and $107.3 \mathrm{q} / \mathrm{ha}$ respectively, while Kufri Arun had least mean value (69.2 q/ha).

Table.1 Crop duration and rainfall details

\begin{tabular}{cccccccc}
\hline \multirow{2}{*}{ Location } & \multirow{2}{*}{ Block } & \multicolumn{2}{c}{ Crop duration (Days) } & \multicolumn{2}{c}{ Total rainfall } & \multicolumn{2}{c}{ Effective rainfall } \\
\cline { 3 - 7 } & & 2014 & 2015 & 2014 & 2015 & 2014 & 2015 \\
\hline KVK- I. Farm & Semiliguda & 90 & 88 & 1324 & 780 & 617 & 394 \\
Luhaba & Semiliguda & 92 & 89 & 1266 & 798 & 625 & 391 \\
Muliaput & Nandapur & 91 & 90 & 1168 & 481 & 591 & 316 \\
Jhaliaguda & Jeypore & 89 & 92 & 1409 & 1090 & 598 & 453 \\
\hline
\end{tabular}


Table.2 Details of genotypes analysed for stability analysis

\begin{tabular}{|c|c|c|c|}
\hline Sl. no. & Genotype & Year of release & Parents \\
\hline 1. & Kufri Jyoti & 1968 & $3069 \mathrm{D}(4) \times 2814 \mathrm{~A}(1)=\mathrm{SLB}-\mathrm{Z389}(\mathrm{B})$ \\
\hline 2. & Kufri Chandramukhi & 1968 & SD. $4485 \times$ K. KUBER= A2708 \\
\hline 3. & Atlantic & 1978 & WAUSEON $\times$ USDA B5141-6 \\
\hline 4. & Kufri Badshah & 1979 & JYOTI $\times$ ALKR=JF4870 \\
\hline 5. & Kufri Bahar & 1980 & K RED $\times$ GINEKE $=E 3797$ \\
\hline 6. & Kufri Lalima & 1982 & K RED $\times$ AG14(WISX37=BS/C-1753 \\
\hline 7. & Kufri Ashok & 1986 & EM/C-1021 × CP1468 \\
\hline 8. & Kufri Pukhraj & 1998 & CRAGS DEFIANCE $\times$ JE $\times /$ B-687JE $\times / C 166$ \\
\hline 9. & Kufri Chipsona-1 & 1998 & $\mathrm{MP} / 90-83=\mathrm{CP} 2416 \times \mathrm{MS} / 78-79$ \\
\hline 10. & Kufri Kanchan & 1999 & SLB/Z-405 × PIMPERNEL \\
\hline 11. & Kufri Arun & 2005 & MS/92-2105=K LALIMA $\times$ MS-82-797 \\
\hline 12. & Kufri Pushkar & 2005 & QB/A-9-120 × CB-1462 \\
\hline 13. & Kufri Lalit & 2006 & $85-\mathrm{P}-670 \times$ CP 192 \\
\hline 14. & Kufri Surya & 2006 & $\mathrm{CP}-3098 \times \mathrm{MS} / 90-512$ \\
\hline 15. & Kufri Chipsona-3 & 2006 & KCHIPS $2 \times$ MP/91-86 \\
\hline 16. & Kufri Khyati & 2008 & MS/82-638 × K. PUKHRAJ \\
\hline
\end{tabular}

Table.3 Site description and details of soil properties

\begin{tabular}{|c|c|c|c|c|c|c|c|}
\hline Location & Block & Texture & pH & $\begin{array}{l}\mathrm{EC} \\
\left(\mathrm{dSm}^{-1}\right)\end{array}$ & $\begin{array}{l}\text { OC } \\
(\%)\end{array}$ & $\begin{array}{l}\text { P } \\
\left(\mathrm{kgha}^{-1}\right)\end{array}$ & $\begin{array}{l}\text { K } \\
\left(\mathrm{kgha}^{-1}\right)\end{array}$ \\
\hline KVK- I. Farm & Semiliguda & Gravel loamy & 6.1 & 0.25 & 0.68 & 15.4 & 250 \\
\hline Luhaba & Semiliguda & Loamy & 5.7 & 0.31 & 0.79 & 12.9 & 364 \\
\hline Muliaput & Nandapur & Fine loamy & 6.3 & 0.24 & 0.89 & 13.0 & 205 \\
\hline Jhaliaguda & Jeypore & $\begin{array}{l}\text { Clayey } \\
\text { skeletal }\end{array}$ & 7.5 & 0.35 & 0.71 & 16.2 & 231 \\
\hline
\end{tabular}

Table.4 Mean Squares due to different source of variation for various quality traits in Potato (Solanum tuberosum L.)

\begin{tabular}{|l|c|c|c|}
\hline Source of variation & dof & Yield/plant $(\mathbf{g})$ & Marketable yield (q/ha) \\
\hline Genotype & 15 & $496.9^{* *}$ & $552^{* *}$ \\
\hline Environment & 3 & $1278^{* *}$ & $321^{* *}$ \\
\hline Genotype $\times$ Environment & 45 & 52.0 & $13.2^{*}$ \\
\hline Environment (Linear) & 1 & $3834^{* *}$ & $963.8^{* *}$ \\
\hline Environment $\times$ Genotype (Linear) & 15 & $80.60^{* *}$ & $18.94^{* *}$ \\
\hline Pooled error & 120 & 20.01 & 7.96 \\
\hline Pooled deviation & 32 & 35.35 & 9.70 \\
\hline $\begin{array}{l}\text { *significant at 5\% level of significance } \\
* * \text { significant at 1\% level of significance }\end{array}$ \\
\hline
\end{tabular}


Table.5 Mean value, regression coefficient (bi) and variation due to deviation $\left(\mathrm{s}^{2} \mathrm{di}\right)$ for 16 potato genotypes

\begin{tabular}{|c|l|l|l|c|c|c|}
\hline \multirow{2}{*}{ Genotypes } & \multicolumn{3}{|l|}{ Yield/plant } & \multicolumn{3}{l|}{ Marketable yield (q/ha) } \\
\cline { 2 - 7 } & Mean & bi & $\mathrm{S}^{2} \mathrm{di}$ & Mean & bi & $\mathrm{S}^{2} \mathrm{di}$ \\
\hline Kufri Kanchan & 165 & $0.90^{* *}$ & -33 & 86.4 & $1.19^{*}$ & 18.40 \\
\hline Kufri Pukhraj & 177 & 0.30 & $125^{*}$ & 107.4 & 0.31 & 8.96 \\
\hline Kufri Chipsona 3 & 178 & $0.32^{* *}$ & -40 & 102.6 & $0.77^{*}$ & 1.38 \\
\hline Kufri Badshah & 152 & $0.70^{* *}$ & -25 & 79.8 & $0.95^{* *}$ & -6.57 \\
\hline Kufri Arun & 145 & $1.58^{* *}$ & -3 & 69.2 & $0.85^{* *}$ & -7.85 \\
\hline Kufri Ashok & 173 & $1.15^{* *}$ & -9 & 105.4 & $0.92^{* *}$ & -5.50 \\
\hline Kufri Chipsona 1 & 162 & $1.06^{* *}$ & -12 & 87.3 & $1.46^{* *}$ & -4.67 \\
\hline Kufri Puskar & 157 & $1.82^{* *}$ & -19 & 95.2 & $2.65^{* *}$ & 14.72 \\
\hline Atlantic & 164 & $2.14^{* *}$ & 7 & 85.7 & $1.60^{* *}$ & -5.68 \\
\hline Kufri Lalima & 175 & $0.53^{* *}$ & -32 & 104.1 & 0.49 & 3.11 \\
\hline Kufri Bahar & 165 & $1.54^{* *}$ & 40 & 87.3 & 0.97 & 20.84 \\
\hline Kufri Lalit & 181 & 0.20 & -24 & 104.2 & 0.43 & -1.63 \\
\hline Kufri Khyati & 181 & $0.53^{* *}$ & -40 & 102.5 & $0.67^{*}$ & 1.04 \\
\hline Kufri & & & & & & \\
Chandramukhi & 157 & $0.98^{* *}$ & -36 & 81.9 & $0.77^{* *}$ & -6.94 \\
\hline Kufri Surya & 167 & $1.48^{* *}$ & -40 & 86.4 & $1.17^{* *}$ & -7.22 \\
\hline Kufri Jyoti & 182 & $0.76^{*}$ & 1 & 107.3 & $0.79^{*}$ & 5.51 \\
\hline Population mean & 167.6 & & & 93.3 & & \\
\hline $\begin{array}{l}* \text { significant at 5\% level of significance } \\
* * \text { significant at 1\% level of significance }\end{array}$ & & & & \\
\hline
\end{tabular}

Figure.1 Linear regression of yield/planton environment indices showing different genotypes

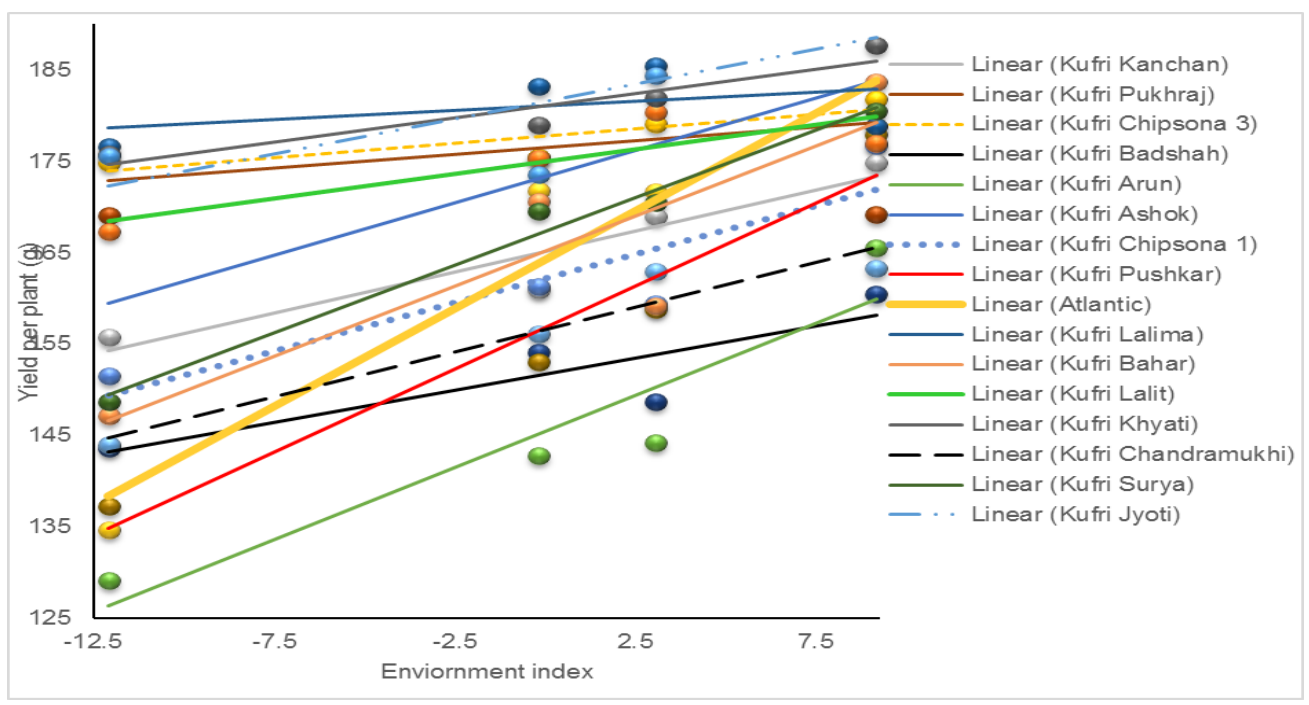


Figure.2 Linear regression of marketable yield on environment indices showing different genotypes

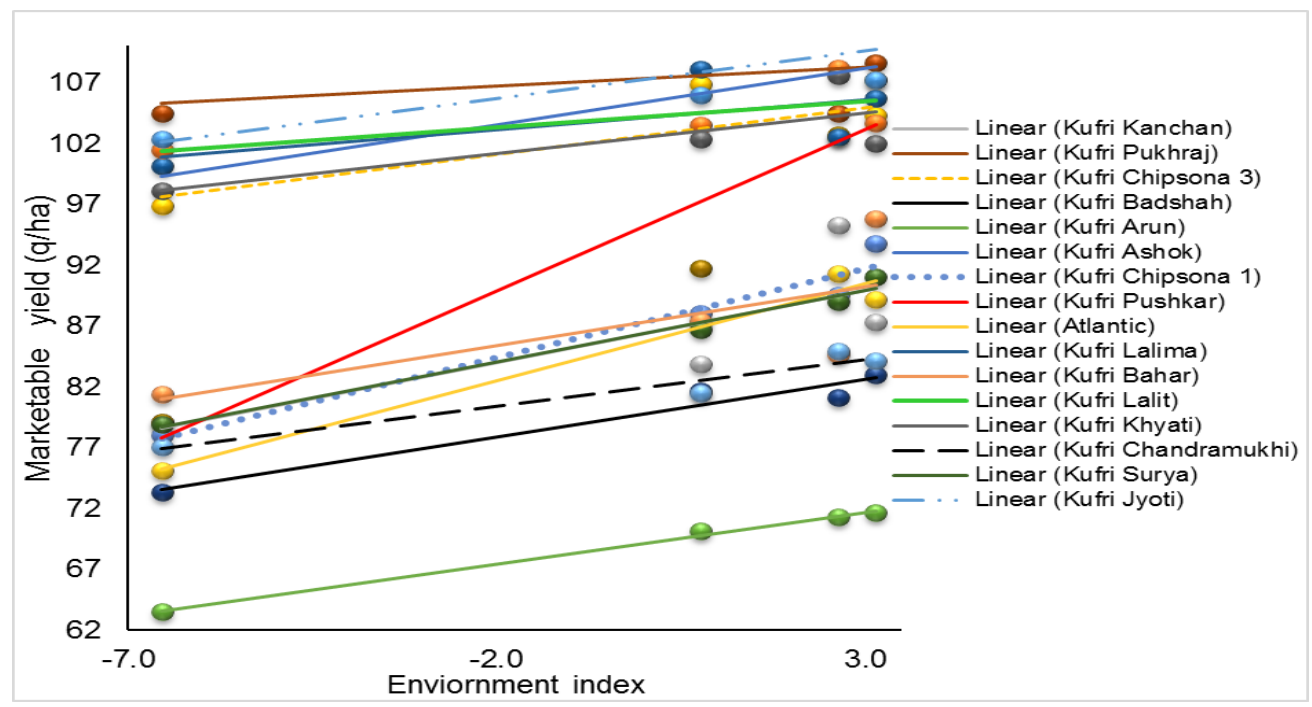

Figure.3 Relationship between regression coefficients and mean yield/plant for 16 potato genotypes

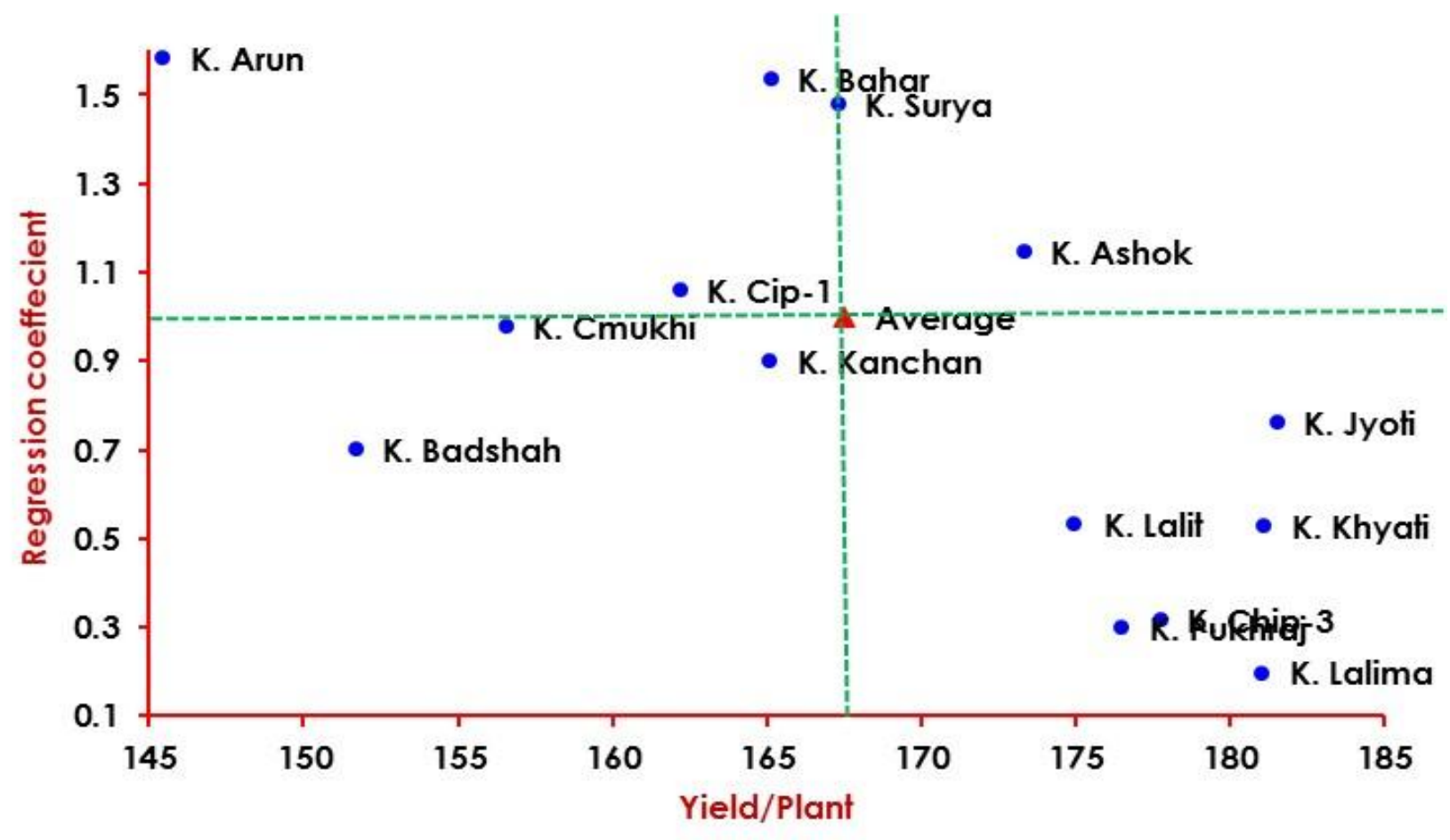


Figure.4 Relationship between regression coefficients and mean marketable yield for 16 potato genotypes

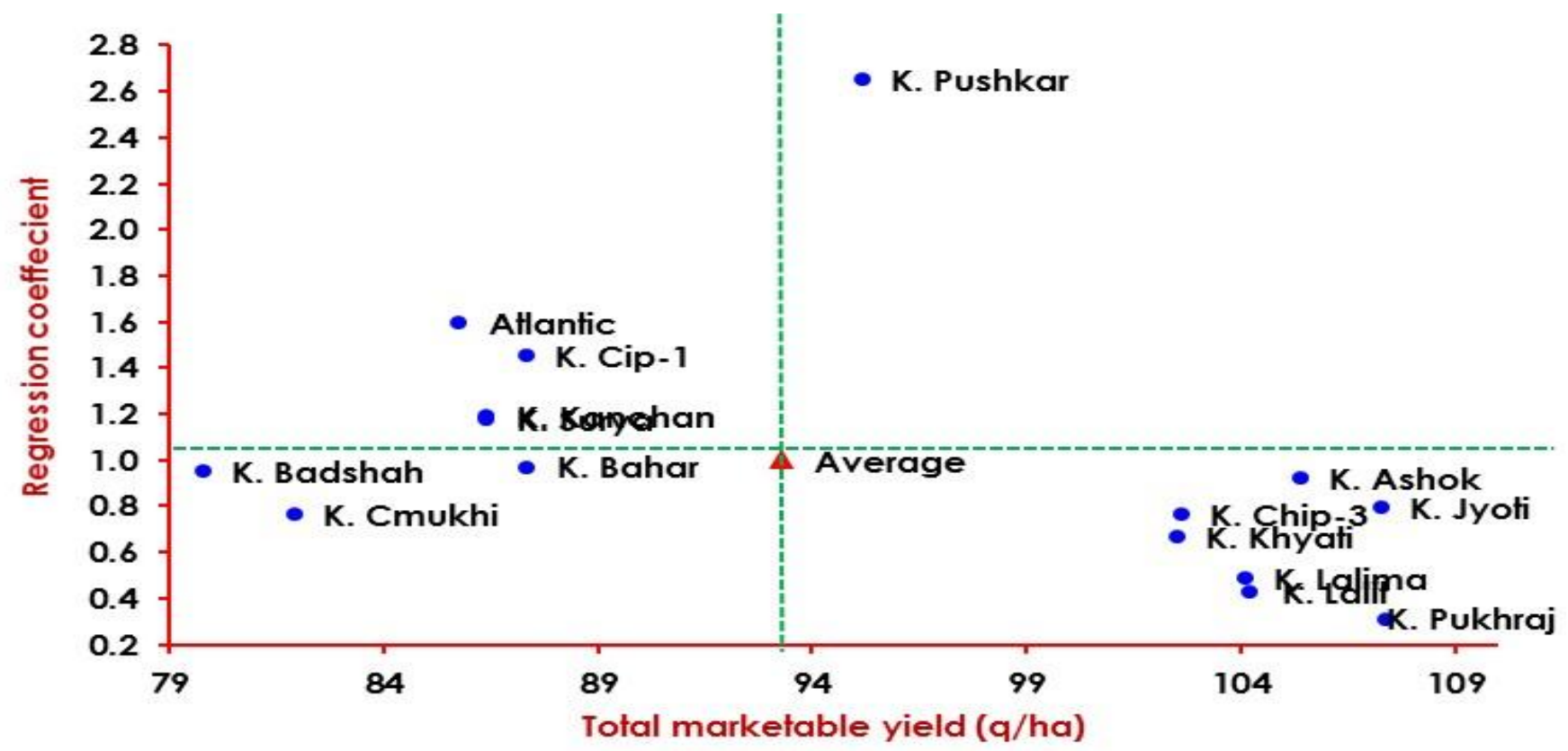

For regression coefficient the genotypes Kufri Lalima, Kufri Pukhraj, Kufri Lalit remained non-significant while Kufri Khyati, Kufri Jyoti, Kufri Chipsona 3 and Kufri Kanchan showed significance at $5 \%$ probability level. The regression coefficient of Kufri Ashok, Kufri Chipsona 3, Kufri Jyoti, Kufri Bahar, Kufri Badshah and Kufri Surya was entangled approximately to 1 . This signs their adaptability to all the 4 locations. Similar results for Kufri Lalit, Kufri Jyoti and Kufri Chipsona 3 at Meerut were reported by Singh et al., (1999) in an assessment of 24 potato genotypes. While Kufri Surya and Kufri Chandramukhi with lower mean than population mean and regression coefficient approaching unity are considered as genotypes poorly adapted to all the environments. Kufri Bahar with lower mean yield than the population mean and unit regression coefficient was registered as unstable for all the environments. Kufri Lalima, Kufri Khyati and Kufri Pukhraj showed regression coefficient less 1 than but mean greater than population mean. Hence these genotypes were classified as specifically adapted to poor (unfavourable) environments. Remaining genotypes marketable yield values deviated significantly from regression hence found unstable over all location for kharif cultivation.

Adaptability is the result of homoeostasis which refers to the buffering capacity of a genotype to environmental fluctuation. Genetically homogeneous populations such as pure line varieties depend heavily on individual buffering to stabilise productivity (Allard and Bradshaw, 1964). General adaptability of Kufri Lalima, Kufri Pukhraj, Kufri Lalit, Kufri Khyati, Kufri Jyoti and Kufri Ashok to different locations might be ascribed to their greater individual buffering ability. Of the 16 varieties evaluated; Kufri Lalit, Kufri Lalima, Kufri Pukhraj and Kufri Jyoti showed better adaptability for both the characters. Based on the yield/plant and marketable yield the mentioned varieties can be recommended to farmers for cultivation for off-season potato cultivation in Koraput region. 


\section{References}

Ali, N., F. Javidfar and Y. Mirza. 2003. Selection of stable rapeseed (Brassica napus L.) genotypes through regression analysis. Pak. J. Bot., 35: 175-183.

Allard, R.W. and Bradshaw, A.D. 1964. Implications of genotype environment interaction in applied plant breeding. Crop Sci., 4: 503-598.

Becker, H.B. and Leon, J. 1988. Stability analysis in plant breeding. Plant Breed. 101: 1-23.Crossa, J. 1990. Statistical analysis of multi-location trials. $A d v$. Agron., 44: 55-85.

Eberhart, S.A. and Russell, W.A. 1966. Stability parameters for comparing varieties. Crop Sci., 6: 36-40.

Finlay, K.W. and Wilkinson, G.N. 1963. The analysis of adaptation in a plant breeding programme. Australian $J$. Agri. Res., 14: 742-754.

Haydar, A. Islam, M.A., Ara, T., Khokan, E.H. and Hossain, M.M. 2009. Stability analysis for tuber yield components in potato. Int. J. Sustainable Crop Production, 4(4): 1-4.

Hebert, Y., C. Plomion and N. Harzic. 1995. Genotypic x environment interaction for root traits in maize as analysed with factorial regression models. Euphytica, 81: 85-92.

Lin, C.S., Binns, M.R. and Lefkovitch, L.P. 1986. Stability analysis: Where do we stand? Crop Sci., 26: 894-900.

Luthra, S.K., Gopal, J., Singh, B.P. and Pandey, S.K. 2009. Stability for tuber yield and its components in potato. Potato J., 36(1-2): 20-24.
Mevlut, A., Yuksel, K. and Seyfi, T. 2005. Genotype-Environment Interaction and Phenotypic Stability Analysis for Grain Yield of Durum Wheat in the Central Anatolian Region Turk J. Agri., 29: 369-375.

Nagaraja, M.S., Halagundegowda, G.R., Meenakshi, H.K. and Krishnamurthy, K.N. 2017. Regression Analysis to Identification of Stable Genotypes of Finger Millet for Plant Height across India. Int. J. Curr. Microbiol. App. Sci., 6(2): 1179-1186. doi http://dx.doi.org/10.20546/ijcmas.2017. 602.133

Patel, R.N., Patel, N.H., Pandey, S.K., Patel, J.M., Kanbi, V.H. and Patel, C.K. 2008. Adaptability of some potato cultivars in North Gujarat. Potato J., 35(1-2): 1922.

Singh, S.V., Gaur, P.C. and Pandey, S.K. 1999. Phenotypic stability of advanced hybrids for yield in early and main potato (Solanum tuberosum) crop. Indian J. Agri. Sci., 69(3): 217-219.

Spaldon, S., Samnotra, R.K., Dolkar, R. and Choudhary, D. 2017. Stability Analysis and Genotype $X$ Environment Interaction of Quality Traits in Tomato (Solanum lycopersicum L.). Int. J. Curr. Microbiol. App. Sci., 6(2): 1506-1515. doi:http://dx.doi.org/10.20546/ijcmas.2 017.602 .168

Tesemma, T., Tsegaye, S. Belay, G. Bechere E. and Mitiku. D. 1998. Stability of performance of tetraploid wheat landraces in Ethiopian highland. Euphtytica, 102: 301-308.

\section{How to cite this article:}

Jyotshnarani Maharana, C.M. Panda and Praveen Jakhar. 2017. Genotype $\times$ Environment Interaction and Stability Analysis of Kharif Potato in Koraput Region of Odisha. Int.J.Curr.Microbiol.App.Sci. 6(5): 1159-1166. doi: https://doi.org/10.20546/ijcmas.2017.605.126 